\title{
PETER LAUGESEN
}

\section{ÅNDELIG FØDE}

If music be the food of love, play on;

Give me excess of it, that, surfeiting,

The appetite may sicken, and so die. (Shakespeare: Twelfth Night; Or, What You Will)

Forleden var der en, der kunne huske en linje af et af mine digte. Det blev refereret til mig i telefonen og linjen var: „Jeg har skidt i dag“.

Jeg ved godt, hvilken linje i hvilket digt den følsomt erindrende husker, men han husker forkert. Det er ikke en linje, men tre, og de står i et langt digt om en dag i Thylejren. Trykt i en bog, der hedder Himmel karlighed frihed. den udkom i 1982. Et uddrag:

$$
\begin{aligned}
& \text { står i regnen } \\
& \text { og blir en myre } \\
& \text { på en gren } \\
& \text { stjerner } \\
& \text { bjælder } \\
& \text { og trompeter } \\
& \text { jeg har } \\
& \text { slet ikke } \\
& \text { skidt i dag }
\end{aligned}
$$

Huskeren husker altså ikke bare forkert, han har også glemt den midterste centrale linje i den tredelte strofe. Det er også længe siden, så det skal være ham tilgivet. Alligevel siger det en del om den almindelige holdning til moderne poesi. Den er brovtende, bøvet, ekskremental, infantil og blottet for betydning.

Man kan altid diskutere, hvem det egentlig er, der brovter her, mens Clifford Brown puster Smoke Gets in Your Eyes gennem trompeten, men den tredelte strofe, hvoraf huskeren har glemt midterstykket, har selvfølgelig en funktion i digtets fortælling. Det var ikke så nemt at skide i Thylejren dengang, hvis man var en lille smule normalt blufærdig. Dele af befolkningen mente, at den slags handlinger burde udføres i fuld offentlighed, $i$ skure uden dør, så man ligesom kunne lære hinanden at kende, ikke. Og i almindelig 
freudiansk tænkning, især af den lavere slags, der ikke er baseret på noget kendskab til Freud overhovedet, er kunsten, kunstværket, forbundet med infantilt lystfyldt ekskrementbehandling. Ifølge den vil linjerne

jeg har

slet ikke

skidt i dag

altså betyde, at digteren lige den dag ikke har afleveret et digt. Huskeren der glemmer udfører følgelig en decideret fejltolkning, idet han vil mene, at digteren faktisk har afleveret den dag. Og det har han jo sådan set også. Hvis man altså antager, at Freuds teori er rigtig, hvad man for min skyld for så vidt udmærket kan gøre, da den ikke er helt forkert.

Kunstneren indtager bestemt noget for at kunne udst $\varnothing$ de og behandle det $\mathrm{i}$ en anden form. Der foregår en fordøjelse indimellem. Man kan således sige, at en skulptør som Giacometti skider vandholdig kalciumsulfat, også kaldet gips. Mens man hos en maler som Jackson Pollock må vende sig til en anden udstødningsmekanisme og hævde, at han pisser cykellak. Hvad angår digteren er det straks lidt mere indviklet, idet hans materiale jo er sproget, som følgelig må være noget lort.

Ligesom musikken er en manipulation af støj. En manipulation der, ifølge en ekspert i de sager som Shakespeare, se indledningscitatet, endda er „kærlighedens føde“. Spil videre, siger han, indtil jeg får for meget, så jeg brækker mig. Og vupti: Kunst! Warhol der pisser på en trykplade! Twelfth Night eller hvad fanden du vil!

Det er et fortolkningsspørgsmål. For slet ikke at tale om de peristaltiske effekter af dans, Bournonville, Alvin Auley, Trisha Brown. 